\title{
SIMPLE, COST-EFFECTIVE TECHNIQUE FOR PORTABLE DIGITAL ELECTROCORTICOGRAPHY
}

\author{
PAULO R. M. DE BITTENCOURT*, MARCOS C. SANDMANN*, \\ MARLUS S. MORO**, JOÃO C. DE ARAÚJO**
}

\begin{abstract}
We revised 16 patients submitted to epilepsy surgery using a new method of digital, real-time, portable electrocorticography. Patients were operated upon over a period of 28 months. There were no complications. The exam was useful in 13 cases. The low installation and operational costs, the reliability and simplicity of the method, indicate it may be useful for defining the epileptogenic regions in a variety of circumnstances, including surgery for tumors, vascular malformations, and other cortical lesions associated with seizure disorders.
\end{abstract}

KEY WORDS: epilepsy, epilepsy surgery, EEG, EcoG.

\section{Eletrocorticografia digital portátil: uma técnica simples e de boa relação custo versus benefício}

RESUMO - Revisamos 16 pacientes submetidos a cirurgia de epilepsia utilizando um novo método de eletrocorticografia digital, portátil, em tempo real. Os pacientes foram operados num período de 28 meses. Não ocorreram complicações. A eletrocorticografia digital foi útil em 13 casos. O baixo custo de instalação e operação, a confiabilidade e simplicidade do método indicam que ele pode ser útil para definir as regiões epileptogênicas em uma variedade de circunstâncias, inclusive cirurgias de tumores, malformações vasculares, e outras lesões corticais.

PALAVRAS-CHAVE: epilepsia, cirurgia de epilepsia, EEG, ECoG.

The indications of invasive EEG techniques have decreased with the rapid progress observed in the field of epilepsy surgery over the past decade ${ }^{1}$. Most centers now carry out invasive EEG techniques in less than $50 \%$ of the cases. The majority of patients may nowadays have their epileptogenic regions identified by non-invasive investigation, including videomonitoring of seizures, magnetic resonance imaging, single-photon emmission computerized tomography, and neuropsychological investigation ${ }^{1}$. In the same period a number of different invasive techniques have been developed, including the placement of grids and strips of electrodes in the subdural space $e^{2,3}$. These refinements have been added to the standard electrocorticography $(\mathrm{EcoG})^{4,5}$ and intracerebral depth electrodes (6), developed many decades ago. In all these techniques the patients need to be connected to large, complex electrical and digital equipment, with consequent requirements of electrical safety and constraints on the quality of the recordings made. These requirements are more stringent than usual in the case of ECoG given the fact that recordings are being made on the brain surface or very close to it ${ }^{7}$.

Invasive EEG may be subdivided in surgical and extra-surgical. The former includes ECoG and depth electrodes. The latter includes subdural and depth electrodes. Surgical invasive EEG, traditionally, has been carried out in dedicated rooms, where a glass wall separates the actual surgical

*Services of Neurology and Neurophysiology and **Neurosurgery, Epilepsy Surgery Program, Hospital N S das Graças, Curitiba, Brazil. Aceite: 19-fevereiro-2000.

Dr. Paulo R. M. de Bittencourt, PhD - Rua Padre Anchieta 155 - 80410-030 Curitiba PR - Brasil. FAX 41223 3699. E-mail: unineuro@bsi.com.br 
room from a compartment with an array of equipment, operated by a technician and monitored by a clinical neurophysiologist ${ }^{8}$. Decision making is usually made by an agreement between surgeon and neurophysiologist.

In this paper we present a very much cheaper, simpler and safer alternative to the traditional method, using a commercially available 32-channel digital portable electroencephalograph to carry out successful real-time EcoG.

\section{METHOD}

All patients had been entered in the Hospital Nossa Senhora das Graças Epilepsy Surgery Program ${ }^{9,10}$. All had epilepsy resistant to medication and had undergone videomonitoring of seizures with extracranial and sphenoidal electrodes, as well as neuroimaging and neuropsychological studies, including the amytal test when necessary ${ }^{11}$. ECoG was indicated when the border of cortical resection needed to be defined intra-operatively, as judged by the neurologist, neurophysiologist and neurosurgeons. A total of 16 patients underwent the new ECoG technique between December 1996 and April 1999.

A Grass ECoG crown was used in all cases. Its output was connected directly into the cable of a standard Medelec Discovery, a 32-channel, fully digital electroencephalograph, placed above the legs of the patient, in full view of the surgeons.

The EEG technician, a trained nurse, installed the equipment in the room just before surgery. She was called by the surgeons when they approached the time when recording was to begin, Usually, the neurophysiologist interpreted the EcoG recorded from a region surrounding a lesion detected by MRI (Table 1), in order to help

Table 1. Identification, demographics, site and nature of epileptogenic lesions in 16 patients submitted to digital EcoG.

\begin{tabular}{|c|c|c|c|c|c|c|}
\hline Initials & $\begin{array}{c}\text { Age } \\
\text { (years) }\end{array}$ & Gender & Site of lesion & Nature & $\begin{array}{c}\text { Follow-up } \\
\text { (months) }\end{array}$ & Result \\
\hline LOS & 21 & $\mathrm{~F}$ & $\mathrm{TL}+\mathrm{FL}$ & MTS+gliosis & 28 & $1 \mathrm{~A}$ \\
\hline NBO & 0.5 & $\mathrm{~F}$ & FL & gliosis & 28 & $3^{\mathrm{A}}$ \\
\hline WB & 25 & M & $\mathrm{TL}+\mathrm{FL}$ & MTS+gliosis & 25 & $3^{\mathrm{A}}$ \\
\hline $\mathrm{JL}$ & 02 & $\mathrm{~F}$ & FL & $\begin{array}{l}\text { tuberous } \\
\text { sclerosis }\end{array}$ & 24 & $2 \mathrm{~A}$ \\
\hline CGS & 23 & M & FL & FCD & 24 & $2^{\mathrm{A}}$ \\
\hline PK & 24 & M & FL & $\begin{array}{l}\text { haemorrhage } \\
\text { +necrosis }\end{array}$ & 22 & $2^{\mathrm{A}}$ \\
\hline TMF & 20 & M & FL & $\begin{array}{l}\text { haemorrhage } \\
\text { +gliosis }\end{array}$ & 23 & $3 \mathrm{~A}$ \\
\hline CAT & 32 & M & PL & $\begin{array}{l}\text { haemorrhage } \\
+ \text { gliosis }\end{array}$ & 13 & $1 \mathrm{~A}$ \\
\hline ES & 37 & M & $\mathrm{TL}+\mathrm{FL}$ & MTS+gliosis & 20 & 1B \\
\hline JFB & 25 & $\mathrm{~F}$ & PL & $\begin{array}{l}\text { haemorrhage } \\
+ \text { gliosis }\end{array}$ & 19 & $4 \mathrm{~A}$ \\
\hline CEZ & 40 & M & FL & cavernous angioma & 15 & $1^{\mathrm{A}}$ \\
\hline MT & 24 & $\mathrm{~F}$ & FL & gliosis & 11 & $4^{\mathrm{A}}$ \\
\hline LSZ & 37 & M & FL & cavernous angioma & 11 & $1^{\mathrm{A}}$ \\
\hline FSF & 06 & $\mathrm{~F}$ & PL & gliosis & 10 & $2^{\mathrm{A}}$ \\
\hline RT & 42 & M & PL & $\mathrm{NA}$ & 0 & NA \\
\hline JG & 37 & M & FL & NA & 0 & NA \\
\hline
\end{tabular}

Results of surgery and follow-up, according to the classification of Engel ${ }^{12}$. PK had 2 surgical procedures; CAT and MT had 2 surgical procedures, subdural grid and cortical stimulation; FSF had subdural grid with cortical stimulation.

F, female; M, male; FL, frontal lobe; TL, temporal lobe; PL, parietal lobe; MTS, mesial temporal sclerosis; FCD, focal cortical displasia; NA, not available. 
determine the amount of tissue to be resected. His decision making, in accord with the surgeons, was based on real-time, on-line recordings. Once that task had been completed a second recording was carried out to make sure all the epileptogenic tissue had been eliminated. In case the neurophysiologist and surgeons decided there was too much epileptogenic activity remaining, more tissue was resected, and a third round of recordings were made. This routine could be continued for as many times as necessary.

\section{RESULTS}

Details of the 16 patients are shown in Table 1. Appropriate recordings were obtained in all of patients, and ECoG was considered useful in 13 of the patients. There were no complications. The results of surgery were compatible with the complex nature of the pathologies observed (Table 1). There were 5 excellent , 4 average, and 5 acceptable results in 14 cases followed for more than 10 months after surgery.

\section{DISCUSSION}

The technique demonstrated here may cause a democratization of invasive EEG in epilepsy surgery, and perhaps in neurosurgery of other conditions, too. The equipment we used has a total cost of less than US\$25000.00, and is routinely used for routine EEG in various sites in the same hospital and in remote sites. Sitting on a simple wheeled cart it is taken routinely to pediatric, general, neonatal and cardiac intensive care units, and frequently recordings of patients are made on the bedside for a number of reasons. Occasionally the machine travels in a taxi to record EEGs, routine or for diagnosis of cerebral death.

Many machines similar to the one used are becoming commercially available. This technological progress may have some simple and some more complex consequences. The greatest advantages of the portable digital electroencephalograph are simplicity of use, low acquisitional and operational cost, and high degree of security. In fact, these machines are portable, so their insulation is fully contained in the machine itself. In fact, were it not for this method, we would not have been able to develop ECoG in our hospital. We believe that this equipment is much safer eletrically than the paper machines improvised in some centers, and it is incomparably cheaper and simpler to use than the complex equipment installed in the more affluent centers.

One possible disadvantage of the method as we devised is not having paper recordings to check on when doubt arises. We found that this did not happen. Eventhough records were in the memory of the recorder, there was not an opportunity when neurophysiologists or neurosurgeons decided to go back and check. Another potential problem was the small size of the screen where recordings were shown. This also proved a false problem, because the neurophysiologist and the technician were well accustomed to working with the same equipment daily in complex EEGs such as those carried out for diagnosis of cerebral death. The large spikes and rhythms of EcoG were comparatively easy to interpret.

In fact, simplicity of use and low cost may prove to be the most complex consequences of the method, because they make the technique much more widely available. We believe that this method has wider application in neurosurgery, as exemplified by the 2 cases of cavernomas shown in table 1, in which ECoG was thought very useful by the surgeons in deciding how far cortical resection should go. In fact, one of the patients had already been operated in the same region before, at another hospital, when the cavernoma was resected, but seizures persisted because the adjoining gliotic area was not. With ECoG this problem was solved. The same rationale would make digital portable ECoG an attractive technique for surgery of all epileptogenic lesions, including tumours, hemorrhages and vascular malformations. This technique, by being widely available, could well be used to bring neurosurgeons to resect epileptic cortex close to the lesions they are used to resect, and perhaps decrease the frequency of epilepsy as a sequel of brain surgery.

Acknowledgement - The authors thank Drs G. Ojemann, F. Andermann, P. Wolf, J. Duncan and H. Lüders for their technical contribution to the development of the Epilepsy Surgery Program at Hospital Nossa Senhora das Graças, Curitiba, Brazil. 


\section{REFERENCES}

1. Engel J Jr. Second Palm Spring Desert Conference on the Surgical Treatment of the Epilepsies (1992). Neurology 1993;43:1612-1617.

2. Arroyo S, Lesser RP, Awad IA, et al. Subdural and epidural grids and strips. In Engel J Jr. (ed). Surgical treatment of the epilepsies. 2.Ed. New York: Raven Press 1993:377-386.

3. Wyler AR, Wilkus RJ, Blume WT. Strip electrodes. In Engel J Jr. (ed). Surgical treatment of the epilepsies, 2.Ed. New York: Raven Press 1993:387-397.

4. Ajmone-Marsan C, Baldwin M. ECoG in the temporal lobe epilepsy. In Baldwin M, Bailey P (eds). Temporal lobe epilepsy. Springfield, IL: Charles C. Thomas, 1958:368-395.

5. Gibbs FA, Amador L, Rich C. Electroencephalografic findings and therapeutic results in surgical treatment of psychomotor epilepsy. In Baldwin M, Bailey P, (eds). Temporal lobe epilepsy. Springfield, IL: Charles C. Thomas, 1958:358-367.

6. Spencer SS, So NK, Engel J Jr, et al. Depth electrodes. In Engel J Jr. (ed). Surgical treatment of the epilepsies. 2.Ed. New York: Raven Press 1993:359-376.

7. Lüders H, Lesser RP, Dinner DS, et al. Commentary: Chronic intracranial recording and stimulation with subdural electrodes. In Engel J Jr. (ed). Surgical treatment of the epilepsies. New York: Raven Press 1987:297-321.

8. Ojemann GA. Intraoperative tailoring of temporal lobe resections. In Engel J Jr. (ed). Surgical treatment of the epilepsies. 2.Ed. New York: Raven Press 1993:481-488.

9. Bittencourt PRM, Araújo JC, Leite PJM, Moro MS, Piana ER, Sandman MC. Epilepsy surgery without invasive EEG: early results of a new program. Arq Neuropsiquiatr 1997;55:542-546.

10. Sandmann MC, Leite PJM, Pontes L, Bittencourt PRM. Early results of a new epilepsy surgery program (Abstr). Epilepsia 1995;36(Suppl.3):S259.

11. Leite PJM, Pereira R, Almeida DF, et al. The intracarotid amobarbital procedure (Wada test) with two protocols combined, Montreal and Seattle. Arq Neuropsiquiatr 1997;55:174-178.

12. Engel J Jr. Outcome with respect to seizures. In Engel J Jr (ed). Surgical treatment of the epilepsies. New York: Raven Press, 1993:565. 